\title{
EFFECT OF BLOOD DONATION ON LIPID PROFILE IN HEALTHY VOLUNTEERS- A SHORT-TERM PILOT STUDY
}

\author{
Sunita Avinash Turankar1, Avinash Vikram Turankar², Seema Vaidya 3 , Saurabh Balpande ${ }^{4}$
}

${ }^{1}$ Ex-Assistant Professor, Department of Biochemistry, Grant Medical College, Mumbai, Maharashtra, India.

${ }^{2}$ Associate Professor, Department of Pharmacology, Government Medical College, Nagpur, Maharashtra, India.

${ }^{3}$ Ex-Professor, Department of Biochemistry, Government Medical College, Nagpur, Maharashtra, India.

${ }_{4}^{4}$ Assistant Professor, Department of Pharmacology, Government Medical College, Nagpur, Maharashtra, India.

\begin{tabular}{l}
\hline ABSTRACT \\
BACKGROUND \\
It is a known fact that giving the blood helps the other in more than one way. One pint of blood given by the donor can save the \\
lives of as many as three individuals.
\end{tabular}

The aim of the study was to estimate the effect of lipid profile after $7^{\text {th }}, 30^{\text {th }}$ and $90^{\text {th }}$ days of blood donation.

\section{MATERIALS AND METHODS}

This is a descriptive study. 30 healthy volunteers were included in the study without any major illness. Total cholesterol was estimated by CHOD-POD method. HDLc was estimated by phosphotungstic acid method. TG was estimated by GPO-POD method. LDLc was estimated by using formula of Friedewald et al.

\section{RESULTS}

All the parameters of lipid profile, e.g. TC, LDL, VLDL except HDL was highly significantly decreased $(p<0.001)$ after 7 th and the effects continued till $30^{\text {th }}$ day after blood donation, which was highly significantly decreased $(\mathrm{p}<0.05$, HDL). It was significantly increased $(\mathrm{p}<0.05)$ after $7^{\text {th }}$ and $30^{\text {th }}$ day of blood donation. At $90^{\text {th }}$ day, all values were normalised.

\section{CONCLUSION}

The act of blood donation has favourable hypolipidaemic effect even in normal healthy volunteers, which starts as early as 7 days and gets normalised by 90 days with continued raised levels of HDL.

\section{KEY WORDS}

Blood Donation, Liquid Profile.

HOW TO CITE THIS ARTICLE: Turankar SA, Turankar AV, Vaidya S, et al. Effect of blood donation on lipid profile in healthy volunteers- a short-term pilot study. J. Evolution Med. Dent. Sci. 2018;7(33):3670-3673, DOI: 10.14260/jemds/2018/824

\section{BACKGROUND}

"Safe Blood starts with me, Blood saves lives" was the WHO theme for 2000 AD.(1) Blood donation is a process by which a blood donor voluntarily has drawn the blood for the shortage in the blood bank or for subsequent use in blood transfusion.(2) There is considerable shortage of blood even in large metropolitan cities with supply being less than $50 \%$ than the requirement. (3)

The donated blood is used for various patients, of the total blood available in blood banks. Following are the indications to patients of acute anaemia caused by surgical haemorrhage, traumatic haemorrhage, non-surgical/ nontrauma haemorrhage, critical illness, early sepsis with inadequate oxygen delivery, septic shock and acute coronary syndrome with ischaemia. The donated blood is also used for various patients. Chronic anaemia caused by chronic blood loss (Hepatic disorders, Bleeding disorders), decreased erythropoiesis (Malignancies, Chemotherapy, Bone marrow, disorders, Renal disorders, Nutritional insufficiencies).(4)

'Financial or Other Competing Interest': None.

Submission 07-03-2018, Peer Review 31-07-2018,

Acceptance 06-08-2018, Published 13-08-2018.

Corresponding Author:

Dr. Avinash Vikram Turankar,

Plot No. 55, Cosmos House,

Trimukta Nagar, Nagpur-440022,

Maharashtra, India.

E-mail: aturankar@hotmail.com

DOI: $10.14260 /$ jemds/2018/824

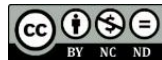

There is a definite benefit to the recipient after the blood donation. But there is also a positive health related impact of blood donation on the donor himself or herself. Some studies have shown that blood donation has potential benefit in coronary artery disease. The study done by Salonen et al. It was found that donation of blood is associated with reduced risk of myocardial infarction. (5)

Study done by Meyers et al and Ascherio et al, it was found that there is a reduction in the cardiovascular events with repeated blood donation and the mechanism proposed by these workers was "Iron Hypothesis."(6),(7)

Few studies also claimed the benefit due to blood donation is because of effect on "Lipid Profile" (Hypolipidaemic effect).(8),(9),(10)

The present study was an effort to find out the strength of the claim in the hypothesis that Blood donation has lipid lowering effect. Also, others have reported the benefit on lipid profile after 3 months and more. We tried to investigate whether this effect is still earlier, i.e. after 7 days or 1 month of donation.

\section{MATERIALS AND METHODS}

This is descriptive study. Blood donation camp was organised in Industrial Training Institute (ITI) in Nagpur. 30 healthy males who were willing to participate were selected for the study. The Inclusion criteria being age between 18 years and 25 years, weight between $50 \mathrm{~kg}$ and $60 \mathrm{~kg}$ and haemoglobin levels should be > $10 \mathrm{mg} \%$. Exclusion criteria being volunteers having history suggestive of chronic illnesses like 
Hypertension, Diabetes Mellitus, Hepatitis B, Haemoglobinopathies, Bleeding disorders, Alcoholics, Chronic smokers, Drug abuser, H/O blood donation within last one month. The samples of 30 healthy volunteers were collected in fasting condition. With all aseptic condition, $5 \mathrm{~mL}$ venous blood was withdrawn and centrifuged. Separated serum was used for further analysis.

Total cholesterol was estimated by CHOD-POD method by using Accurex kit.(11) HDLc was estimated by phosphotungstic acid method by using Accurex kit.(12),(13)

TG was estimated by GPO-POD method by using Accurex kit.(14),(15) LDLc was estimated by using formula of Friedewald et al.(16)

LDLc $=$ TC - HDLc - VLDL and VLDL $=$ TG $/ 5$

The critical level of significance was set at $p<0.05$. The results were analysed by One-Way repeated measures.
ANOVA with Tukey's post test by using trial version GraphPad Prism ver. No. 4 (Trial Version).

\section{RESULTS}

Effect of blood donation on lipid profile.

\section{On Day '7'}

There was statistically significant drop in Total Cholesterol from $(172.4 \pm 6.68)$ to $(136.0 \pm 4.9)[-21.1 \%] ; p<0.001$, LDL from $(90.59 \pm 6.12)$ to $(53.61 \pm 5.191)[-40.82 \%] ; p<0.001$ and TG from $(118.2 \pm 6.87)$ to $(87.07 \pm 6.431)[-26.33 \%] ; \mathrm{p}<$ 0.01 and a fall in VLDL from $(23.64 \pm 1.37)$ to $(17.66 \pm 1.26)[$ $25.3 \%] ; p<0.01$. Whereas, the HDL readings showed a significant rise from $(58.13 \pm 2.02)$ to $(64.74 \pm 1.57)$ $[11.37 \%] \mathrm{p}<0.05$

\begin{tabular}{|c|c|c|c|c|c|}
\hline $\begin{array}{c}\text { Lipid Profile } \\
\text { Parameters }\end{array}$ & $\begin{array}{c}\text { Baseline } \\
\text { (0 Days) }\end{array}$ & $\begin{array}{c}\text { Values (mg\%) } \\
\text { (Day 7) }\end{array}$ & $\begin{array}{c}\text { Actual } \\
\text { Difference }\end{array}$ & Percent & P Value \\
\hline Total Cholesterol & $172.4 \pm 6.68$ & $136.00 \pm 4.97$ & -36.40 & -21.11 & $* * *$ \\
\hline HDL & $58.13 \pm 2.02$ & $64.74 \pm 1.57$ & 6.61 & 11.37 & $*$ \\
\hline LDL & $90.59 \pm 6.12$ & $53.61 \pm 5.19$ & -36.98 & -40.82 & $* * *$ \\
\hline TG & $118.2 \pm 6.87$ & $87.07 \pm 6.43$ & -31.13 & -26.34 & $* *$ \\
\hline VLDL & $23.64 \pm 1.37$ & $17.66 \pm 1.26$ & -5.98 & -25.30 & $*$ \\
\hline \multicolumn{2}{|c|}{} \\
\hline
\end{tabular}

Values shown are Mean + SEM.

$\mathrm{SEM}=$ Standard Error of mean. $\mathrm{P}$ value is in comparison with the Baseline, i.e. Day $0 \mathrm{NS}=$ Not Significant $\mathrm{p}^{*}<0.05^{* *}=\mathrm{p}<0.01^{* * *}$ $=\mathrm{p}<0.001$

\section{On Day '30'}

Effect on Lipid Profile.

There was a continued significant fall as compared with baseline in the levels of Total cholesterol to (152.30 \pm 2.08$)[-11.66 \%]$ $\mathrm{p}<0.05 ;$ LDL to $(67.79 \pm 2.780[-25.17 \%] ; \mathrm{p}<0.01$, TG to $(96.58 \pm 4.49)[-18.29 \%] ; \mathrm{p}<0.05$, VLDL to $(19.32 \pm 0.90)[-18.27 \%] ;$ $\mathrm{p}<0.05$ and significant rise in HDL levels as compared with baseline to $(65.16 \pm 1.33)[12.09 \%] ; \mathrm{p}<0.05$.

\begin{tabular}{|c|c|c|c|c|c|}
\hline $\begin{array}{c}\text { Lipid Profile } \\
\text { Parameters }\end{array}$ & $\begin{array}{c}\text { Baseline } \\
\text { (0 Days) }\end{array}$ & $\begin{array}{c}\text { Values (mg\%) } \\
\text { (Day 30) }\end{array}$ & $\begin{array}{c}\text { Actual } \\
\text { Difference }\end{array}$ & Percent & P value \\
\hline Total Cholesterol & $172.4 \pm 6.68$ & $152.3 \pm 2.081$ & -20.1 & -11.6589 & $*$ \\
\hline HDL & $58.13 \pm 2.02$ & $65.16 \pm 1.33$ & 7.03 & 12.09358 & $*$ \\
\hline LDL & $90.59 \pm 6.12$ & $67.79 \pm 2.78$ & -22.8 & -25.1683 & $* *$ \\
\hline TG & $118.2 \pm 6.87$ & $96.58 \pm 4.487$ & -21.62 & -18.291 & $*$ \\
\hline VLDL & $23.64 \pm 1.37$ & $19.32 \pm 0.8974$ & -4.32 & -18.2741 & $*$ \\
\hline \multicolumn{7}{r}{} \\
\hline
\end{tabular}

Values shown are Mean + SEM.

$\mathrm{SEM}=$ Standard Error of mean. $\mathrm{P}$ value is in comparison with the Baseline i.e. Day 0 NS $=$ Not Significant ${ }^{*}=\mathrm{p}<0.05^{* *}=\mathrm{p}<0.01^{* * *}$ $=\mathrm{p}<0.001$.

\section{On Day '90'}

On lipid profile, the values were Total Cholesterol $(165.20 \pm 4.02)[-4.18 \%]$, HDL $(63.80 \pm 3.93)$ [9.75\%], LDL (78.08 \pm 5.42$)[-$ $13.81 \%]$, TG $(116.60 \pm 3.07)[-1.35 \%]$ and VLDL $(23.32 \pm 3.02)[-1.35 \%]$

\begin{tabular}{|c|c|c|c|c|c|}
\hline $\begin{array}{c}\text { Lipid Profile } \\
\text { Parameters }\end{array}$ & $\begin{array}{c}\text { Baseline } \\
\text { (0 Days) }\end{array}$ & $\begin{array}{c}\text { Values (mg \%) } \\
\text { (Day 90) }\end{array}$ & Actual Difference & Percent & P value \\
\hline Total Cholesterol & $172.4 \pm 6.68$ & $165.2 \pm 4.016$ & -7.2 & -4.17633 & NS \\
\hline HDL & $58.13 \pm 2.02$ & $63.8 \pm 3.932$ & 5.67 & 9.754 & NS \\
\hline LDL & $90.59 \pm 6.12$ & $78.08 \pm 5.42$ & -12.51 & -13.8095 & NS \\
\hline TG & $118.2 \pm 6.87$ & $116.6 \pm 3.074$ & -1.6 & -1.35364 & NS \\
\hline VLDL & $23.64 \pm 1.37$ & $23.32 \pm 0.6148$ & -0.32 & -1.35364 & NS \\
\hline \multicolumn{7}{|l}{ Table 3. Effect of Blood Donation on Lipid Profile on Day 90 } \\
\hline
\end{tabular}

Values shown are Mean + SEM.

$\mathrm{SEM}=$ Standard Error of mean. $\mathrm{P}$ value is in comparison with the Baseline, i.e. Day 0 NS $=$ Not Significant* $=\mathrm{p}<0.05^{* *}=\mathrm{p}<0.01^{* * *}$ $=\mathrm{p}<0.001$ 

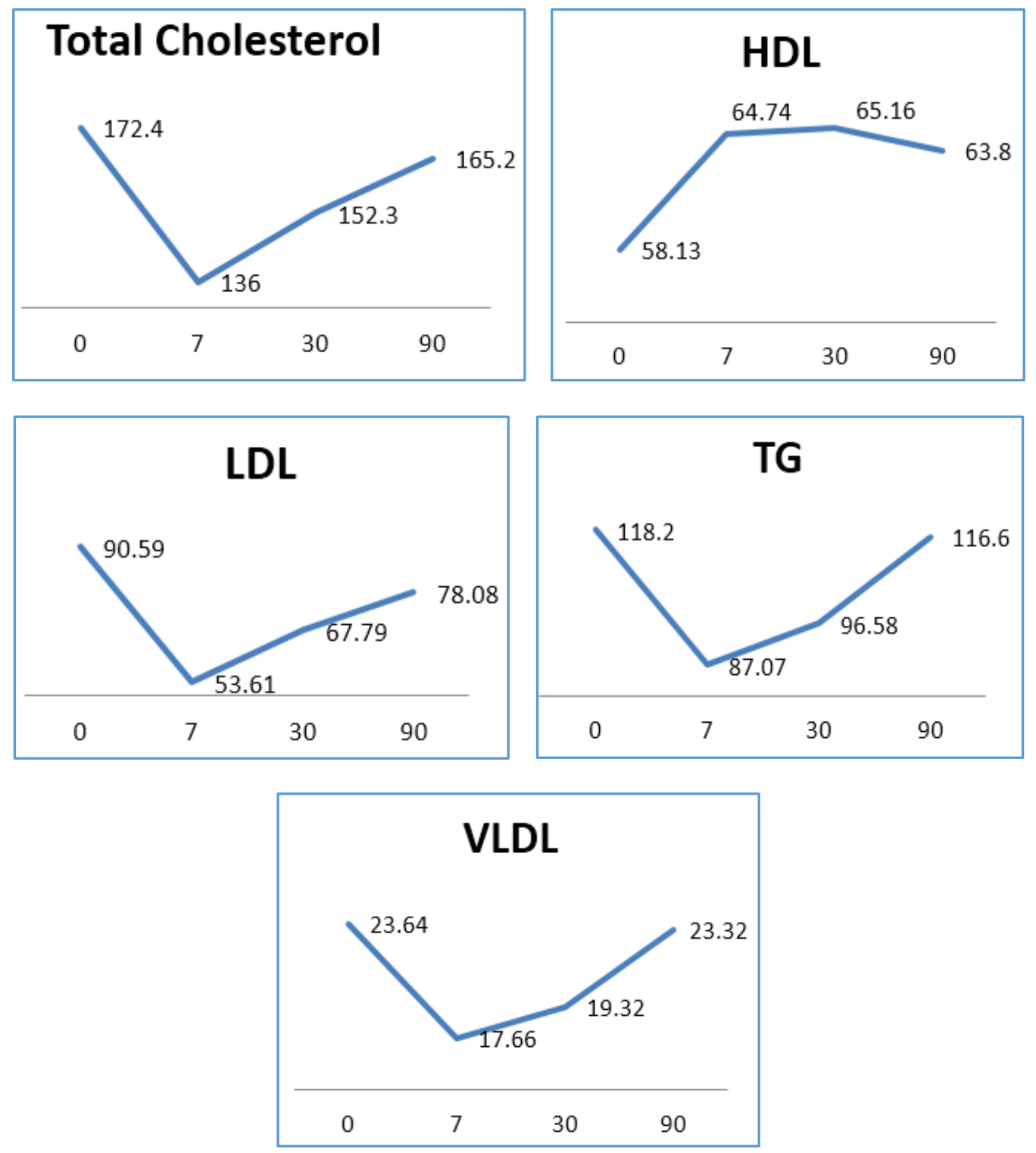

Figure 1. Graph showing Effect of Blood Donation on Lipid Profile in Healthy Volunteers at 7, 30 and 90 days after Blood Donation

\section{DISCUSSION}

\section{At the end of 7 days}

There was a significant drop in Total cholesterol, TG, LDL and in VLDL levels. This drop may be because of utilisation of cholesterol and TG for the synthesis of new cells in the process of erythropoiesis. Blood has cellular components like RBC, WBC, platelets and it is a well-established fact that TG and Cholesterol forms the main structural component of cell membranes.(17) Our study was in agreement with Kaliuzhnyı IT study.(18)

This whole impact on the lipid profile appears to be because of increased demand and less supply of cholesterol by body cholesterol pool.

\section{At the end of $\mathbf{3 0}$ days}

We found significant decrease in lipid profile, except HDL getting normalised at this point of time. Total cholesterol, LDL, VLDL and TG levels were significantly low than baseline and HDL significantly higher than baseline indicating that still the cholesterol is being utilised for erythropoiesis and the rate of regeneration of cholesterol may not be enough to make lipid profile levels to be normal.
There was $10 \%$ significant rise in the levels of HDL cholesterol compared with baseline, which may suggest that the peripheral transport of cholesterol back to liver and then to blood, which is termed as reverse cholesterol transport might still be going on.

\section{At the end of study period, i.e. 90 days}

The levels of TC, LDL, VLDL and TG were more or less restored to normal. The only changes worth noting were of HDL showing 9.8\% rise in levels from baseline values. Our study was in agreement with Kumar H,(19) Mayer DG(20)(6) and Bhardwaj.(1)

Rise in HDL probably may suggest an additional beneficial effect due to increased peripheral transport of HDLcholesterol to meet the increased requirement of erythropoiesis. This process is also known as reverse cholesterol transport. According to Gutteridge JM and Halliwell B in "Iron hypothesis," iron is a potent catalyst for radical production in vitro.(21) The erythropoiesis after blood donation consumes iron and leads to reduction in serum ferritin.(22) The iron-catalysed Fenton reaction generates a range of potent oxidants that can cause oxidation of 
lipids.(23)(24) Similar hypothesis given by [Gebre-Yohannes A,(25) Tommi Pekka(26) and Van Hoydonck PG,(27) Gutteridge JM,(28) Meyers DG(20) Van Jaarsveld H and Pool GF et al,(29) Salonen JT and Tuomainen TP.(5) This causing more generation of oxidative lipid products subsequently leading to more carriage to liver in the form of HDL, hence the raised levels of HDL.

It was short-term study done on normal healthy volunteers with small sample size.

Further studies in repeated blood donors may add newer insights. This may be tested in eligible blood donors with hyperlipidaemia. Role of blood donation can also be explored to find out the preventive role in atherosclerosis in welldesigned studies.

\section{CONCLUSION}

Blood donation has lipid lowering effects as early as 7 days after blood donation and effects were maintained till $30^{\text {th }}$ day after blood donation. During this period, i.e. on day 7 and 30, there was significant decrease in TC, LDL, TG and VLDL levels with significant elevation of HDL concentration. The lipid profile returns to normal after 90 days of blood donation in healthy volunteers.

\section{REFERENCES}

[1] Bharadwaj RS. A study of lipid profiles among male voluntary blood donors in Chennai city. 2005;30(1):01.

[2] Blood donation. Available from: https://en.wikipedia.org/wiki/Blood_donation

[3] Jain J, Dixit M. A cross-sectional study among community on knowledge, attitude and practice about blood donation in Udaipur city of Rajasthan, India. Int J Community Med Public Health 2016;3(4):952-6.

[4] Yaddanapudi S, Yaddanapudi LN. Indications for blood and blood product transfusion. Indian J Anaesth 2014;58(5):538-42.

[5] Salonen JT, Tuomainen TP, Salonen R, et al. Donation of blood is associated with reduced risk of myocardial infarction. The Kuopio Ischaemic Heart Disease Risk Factor Study. Am J Epidemiol 1998;148(5):445-51.

[6] Meyers DG, Strickland D, Maloley PA, et al. Possible association of a reduction in cardiovascular events with blood donation. Heart 1997;78(2):188-93.

[7] Ascherio A, Rimm EB, Giovannucci E, et al. Blood donations and risk of coronary heart disease in men. Circulation 2001;103(1):52-7.

[8] Uche E, Adediran A, Damulak 0, et al. Lipid profile of regular blood donors. J Blood Med 2013;4:39-42.

[9] Clement ANJ, Vincent VS, Shey ND, et al. A crosssectional study on the evaluation of the lipid profile of regular blood donors in the Buea regional hospital, Cameroon. Cardiology and Cardiovascular Research 2017;1(3):76-83.

[10] Eshete EA, Weldemariam TZ. Hematological and lipid profiles of blood donors at redcross center in Addis Ababa. Ethiop Med J 2016;54(1):21-5.

[11] Richmond W. Preparation and properties of a cholesterol oxidase from Nocardia $\mathrm{sp}$. and its application to the enzymatic assay of total cholesterol in serum. Clin Chem 1973;19(12):1350-6.
[12] Castelli WP, Doyle JT, Gordon T, et al. HDL cholesterol and other lipids in coronary heart-disease. The coperative lipoprotein phenotyping study. Circulation 1977;55(5):767-72.

[13] Gordon T, Castelli WP, Hjortland MC, et al. High density lipoprotein as a protective factor against coronary heart disease. The Framingham Study. Am J Med 1977;62(5):707-14.

[14] Wu A. Tietz clinical guide to laboratory tests. $4^{\text {th }}$ edn St. Louis, Mo: WB Saunders 2006: p. 1073-91.

[15] Fossati P, Prencipe L. Serum triglycerides determined colorimetrically with an enzyme that produces hydrogen peroxide. Clin Chem 1982;28(10):2077-80.

[16] Nigam PK. Calculated low density lipoproteincholesterol: Friedewald's formula versus other modified formulas. Int J Life Sci Med Res 2014;4(4):25-31.

[17] Champe PC, Harvey RA, Ferrier DR. Cholesterol and steroid Metabolism. In: Harvey RA, edr. Lippincott's Illustrated Reviews: Biochemistry. $5^{\text {th }}$ edn. Lippincott Williams \& Wilkins 2010: p. 219-44.

[18] Kaliuzhny̌ IT. Functional status of the thyroid gland and blood cholesterol levels of donors (Article in Russian). Probl Endokrinol (Mosk) 1987;33(2):36-9.

[19] Kumar H. Repeated blood donation effective in treating hyperlipidemia. J Assoc Physicians India 1994;42(6):468-9.

[20] Meyers DG, Jensen KC, Menitove JE. A historical cohort study of the effect of lowering body iron through blood donation on incident cardiac events. Transfusion 2002;42(9):1135-9.

[21] Salonen JT, Korpela H, Nyyssönen K, et al. Lowering of body iron stores by blood-letting and oxidation resistance of serum lipoproteins: a randomized cross-over trial in male smokers. J Intern Med 1995;237(2):161-8.

[22] Frei B. Reactive oxygen species and antioxidant vitamins: mechanisms of action. Am J Med 1994;97(3A):5S-13S: discussion 22S-8S.

[23] McCord JM. Is iron sufficiency a risk factor in ischemic heart disease? Circulation 1991;83:1112-4.

[24] Sullivan JL. Blood donation may be good for donor. Iron, heart disease, and donor recruitment. Vox Sang 1991;61(3):161-4

[25] Gebre-Yohannes A, Rahlenbeck SI. Coronary heart disease risk factors among blood donors in northwest Ethiopia. East Afr Med J 1998;75(9):495-500.

[26] Tuomainen TP, Salonen R, Nyyssonen K, et al. Cohort study of relation between donating blood and risk of myocardial infarction in 2682 men in eastern Finland. Br Med J 1997;314(7083):793-4.

[27] Van Hoydonck PGA, Schouten EG, Hoppenbrouwers $\mathrm{KPM}$, et al. Is blood donation induced low iron status associated with favourable levels of OxLDL, s-ICAM-1, sVCAM-1 and vWF-antigen in healthy men. Atherosclerosis 2004;172(2):321-7.

[28] Gutteridge JM, Halliwell B. Iron toxicity and oxygen radicals. Baillieres Clin Haematol 1989;2(2):195-256.

[29] Van Jaarsveld H, Pool GF. Beneficial effects of blood donation on high density lipoprotein concentration and the oxidative potential of low density lipoprotein. Atherosclerosis 2002;161(2):395-402. 